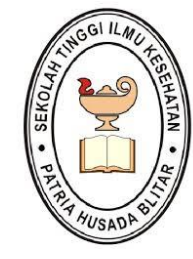

JCSH

JOURNAL OF COMMUNITY SERVICE

FOR HEALTH

http://juda.phb.ac.id/index.php/jcsh

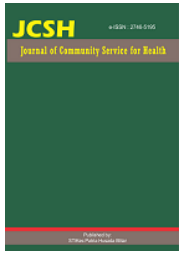

\title{
Education on How to Express and Correct Breast Milk Storage Techniques for Working Mothers
}

\author{
Ika Agustina ${ }^{1}$, Ita Noviasari ${ }^{2}$, Suprajitno ${ }^{3}$ \\ ${ }^{1,2}$ Midwifery Department, STIKes Patria Husada Blitar, Indonesia \\ ${ }^{3}$ Nursing Department, Poltekkes Kemenkes Malang, Indonesia
}

\begin{tabular}{l} 
Article Information \\
\hline History Article: \\
Received, 04/08/2021 \\
Accepted, 19/10/2021 \\
Published, 25/11/2021 \\
\hline
\end{tabular}

Keywords:

Education, Pumping

Breast Milk, Save Breast

Milk, Working Mother

\begin{abstract}
Exclusive breastfeeding for infants up to the age of 6 months reaches $42 \%$ while the WHO target wes at least 50\%. To increase the coverage of breastfeeding, new mothers who have passed leave and have to return to work can carry out the management of Dairy Mother's Milk (ASIP) (Riskesdas, 2013). According to Kristiyansari (2009) working mothers can still breastfeed, before going to work breastfeed their babies first, then at work mothers pump breast milk and store the milk then when they get home the milk is given to the baby or stored in the refrigerator. After giving the counseling, conducting questions and answers and discussions, many asked about how to pump breast milk and how to store breast milk, especially for working mothers. Furthermore, the evaluation was given questions to the mother and can answer even though it is not perfect in providing answers, here it appears that there is an understanding that has been received by the mother after counseling. By being given this counseling, it is hoped that from now on, mothers will learn and not be ashamed to add information to health workers about how to express and the correct technique for storing breast milk for working mothers. So that by the time the mother is working, the mother is ready and able to pump breast milk and the mother can store breast milk properly.
\end{abstract}

(C) 2021 Journal of Community Service for Health

Correspondence Address:

Tribhuwana Tunggadewi University Malang - East Java, Indonesia

E-ISSN : 2746-5195

Email: novita2unitri@gmail.com

DOI: 10.26699/jcsh.v2i2.ART.p047-050

This is an Open Access article under the CC BY-SA license (http://creativecommons.org/licenses/by-sa/4.0/) 


\section{INTRODUCTION}

Breast milk is the best primary food source for infants aged 0-6 months. Meanwhile, according to WHO, exclusive breastfeeding is food given to babies, only breast milk is enough without being given other additions, either food or drinks, starting from birth to 6 months of age (Marimbi, 2010)

Exclusive breastfeeding for infants up to the age of 6 months reaches $42 \%$ while the WHO target is at least $50 \%$. To increase the coverage of breastfeeding, new mothers who have passed leave and have to return to work can carry out the management of Dairy Mother's Milk (ASIP) (Riset Kesehatan Dasar, 2013). Nursing mothers who are working are one of the factors that determine success in exclusive breastfeeding, as evidenced by research that housewives who do not work are 3.5 times more likely to give exclusive breastfeeding. For mothers who work for 8 hours, leaving their babies a lot of opportunities to give breast milk even though only pumping breast milk (Fatimah, 2014)

According to (Kristiyansari, 2009) working mothers can still breastfeed, mothers before leaving for work breastfeed their babies first, then at work mothers can pump breast milk and store the milk then when they get home the breast milk can be given to the baby or stored in the refrigerator. From a survey conducted by interviewing 16 pregnant women, there were 8 pregnant women who worked, it was found that 3 mothers could express breast milk and could store breast milk while the mother was working, then there were 5 mothers who still did not understand the correct storage of breast milk. Based on this incident, we held counseling on how to express and the correct technique for storing breast milk for working mothers.

\section{METHOD}

This community service activity was carried out in 2019 in the class of pregnant women at the Jatinom Polindes, Kanigoro District. First, the event was opened by the Jatinom village midwife then by the village midwife an introduction was made. After the introduction, we continued with the counseling program. Starting the event by reminding mothers about exclusive breastfeeding, how long is exclusive breastfeeding, whether the mother has a lot of breast milk if it gets more, can the mother pump and store breast milk, then do a pre test on how to express breast milk and how to store breast milk correctly from the pre test. this mother already understands or not about how to express breast milk and how to store breast milk correctly.

Tabel 1. Classification of techniques for expressing breast milk and how to store

\begin{tabular}{|c|c|c|c|c|}
\hline \multirow{2}{*}{ breast milk } & \multicolumn{2}{|c|}{ before } & \multicolumn{2}{|c|}{ after } \\
\hline & $\mathrm{f}$ & $\%$ & $\mathrm{f}$ & $\%$ \\
\hline can't do technique & 10 & 62,5 & 4 & 25 \\
\hline can do technique & 6 & 37,5 & 12 & 75 \\
\hline total & 16 & 100 & 16 & 100 \\
\hline
\end{tabular}

\section{RESULTS}

Followed by providing counseling on how to express breast milk and how to store breast milk correctly, then ask questions and discuss with the mothers in the pregnant women class. The evaluation was carried out directly by giving questions to the mother after question and answer and discussion. The results were obtained from all the mothers who were present there were 16 mothers, before the counseling we held a question and answer session there were 6 mothers who could answer but there were mothers who were not sure about their opinions. Furthermore, after the counseling we gave, the results of the evaluation by asking questions got 12 mothers who could answer questions about how to express milk and could do the correct technique of storing breast milk.

\section{DISCUSSION}

Counseling on how to express and proper
breast milk storage techniques for working
mothers.

Exclusive breastfeeding can be done to all mothers, including working mothers. Working mothers can take their time at work to express breast milk every 2 or 3 hours and the time to pump or express breast milk also does not take a long time. Now many institutions or workplaces understand about exclusive breastfeeding, so there are several workplaces that provide breastfeeding rooms so that mothers can pump their breast milk. It is very important that mothers who have worked during their last pregnancy approaching birth are equipped with knowledge about how to express breast milk correctly and techniques for storing breast milk. How to express breast milk, when to express breast milk and what is the best place to store breast milk.

Exclusive breastfeeding for six months is an important investment because breast milk provides the best for both mother and baby. Breast milk given to babies is proven to support optimal growth and development of babies and can strengthen the baby's immune system so that babies don't get sick easily and babies are smarter. WHO recommends that breastfeeding be given for six months which we know as exclusive breastfeeding, in this breastfeeding there should be no addition to the baby until six months of the baby's age (Nurdiansyah, 2011)

The benefits of breastfeeding are: babies are smarter by being given breast milk because breast 
milk contains omega-3 fatty acids, DHA, and ARA which are brain building substances, then breast milk is easy to digest, in breast milk there is a lipase enzyme so that the baby's digestive process goes well, breast milk does not cause allergies, the hormone content in breast milk functions for growth and development, by consuming breast milk the baby's vision is better, the heart is healthier, diabetes is rare, and obesity is less likely to occur later, in breast milk calcium and iron are easily absorbed, strong emotional bonds occur between mother and baby. One of the benefits of breastfeeding for mothers is that the mother's body shape will be easier to return to breastfeeding, and there is a strong bond between mother and baby (Nurdiansyah, 2011).

The skills to express or pump mother's milk before work must be mastered first. Breast milk can be pumped by hand or manually, using a manual pump, or using an electric pump. Of the three ways, the mother can choose the most comfortable according to her and do not forget that she must pay attention to cleanliness as well (Nurdiansyah, 2011). The following are ways to pump breast milk, including: before and after pumping the mother must wash her hands first, place a sterilized bottle or container at the bottom of the breast to accommodate the breast milk, massage the breast slowly, position the mother's finger to form the letter $\mathrm{C}$ around the areola or around nipple, avoid pressing the nipple, release the pressure then repeat again, if the flow of milk has stopped, massage until the entire surface of the breast has been massaged, pump the other breast so that the milk continues to come out until the breast no longer feels full (Savitri A. 2018).

The following are the techniques for storing breast milk, namely: breast milk is stored in glass bottles that have been washed clean, there are special bottles for storing breast milk that can be purchased at baby supply stores, breast milk can also be stored in special sterile plastic breast milk bags. The breast milk holder is given the time and date of breastfeeding after expressing. The special container when the mother works to store breast milk bags or breast milk bottles is called a cooler bag. When the mother arrives home, the breast milk is put in the refrigerator and placed in the freezer. If not put in the freezer, breast milk is placed in the refrigerator. To take ASI, it is adjusted to take the ASIP that comes in first or the initial date of milking is chosen, if you want to take ASI from the refrigerator, the ASIP is removed first, then provides hot water in a container and then inserts a breast milk bag or bottle of breast milk into the container. Meanwhile, to take frozen breast milk, the breast milk from the freezer is transferred to the refrigerator at night and then the next day the breast milk is warmed in a container filled with hot water. The shelf life of ASIP stored is: at room temperature for 6 hours, cooler bag with ice cubes for 24 hours, refrigerator for 5 days, one-door refrigerator freezer for 2 weeks, two-door refrigerator freezer for 3 weeks, special freezer with a temperature of $-18^{\circ} \mathrm{C}$. or colder lasts 6 months (Savitri, 2018).

From the delivery of the counseling given, the 16 pregnant women who took part in the class were enthusiastic in listening to the counseling. Although there are only 8 working mothers, 8 other mothers are also enthusiastic to follow. After giving the counseling, conducting questions and answers and discussions, many asked about how to pump breast milk and how to store breast milk, especially for working mothers. Furthermore, for evaluation, questions are given to the mother and the mother can answer even though the answer is not perfect. From this, it can be seen that there is an understanding that the mother has received after the counseling.

\section{CONCLUSIONS}

Based on the results of the evaluation of the counseling given to the mother, from the questions and answers and discussions carried out, it can be concluded that the counseling activities for pregnant women who work found that health education had a positive effect on the mother. Previously, mothers could not and did not understand after receiving counseling, mothers became able and understood how to pump or express breast milk and mothers could store breast milk properly.

\section{SUGGESTIONS}

Expecting mothers to start learning from now on and not be ashamed to add information to health workers about how to express and proper breast milk storage techniques for working mothers. So that by the time the mother is working, the mother is ready and able to pump breast milk and the mother can store breast milk properly.

\section{REFERENCE}

Fatimah (2014) 'Asi Untuk Kesehatan Bayi', in. Jakarta: EGC.

Kristiyansari (2009) 'Asi, Menyusui dan Sadari', in. Yogyakarta: Nuha Medika.

Marimbi (2010) 'Tumbuh Kembang, Status Gizi \& Imunisasi Dasar Pada Balita', in. Yogyakarta: Nuha Medika.

Nurdiansyah, N. (2011) 'Buku Pintar Ibu \& Bayi', in. Jakarta: Kawah Medika.

Riset Kesehatan Dasar (2013) 'Badan Penelitian 
50 Journal of Community Service for Health, Volume 2, Issue 2, November 2021, page 39-42

dan Pengembangan Kesehatan Kementrian Kesehatan', in.

Savitri, A. (2018) 'Buku Pintar 365 Hari MPASI

Terlengkap', in. Yogyakarta: IDESEGAR

Media Utama. 